\title{
Reviews
}

MICHAEL FIELD is a Pacific journalist and writer whose book on the 2000 Fiji coup is due for publication in May 2005.

\section{Making sense of the Solomon Islands upheaval}

The Manipulation of Custom: From Uprising to Intervention in the Solomon Islands, by Jon Fraenkel. Wellington: Victoria University Press, 2004, 262 pp, ISBN 0864734875.

\begin{abstract}
AALL IT what you like - civil war, unrest or just a disturbance events in the Solomon Islands were for a time greeted indifferently, not only internationally but within the region itself.
\end{abstract}

The problem, perhaps, was that outside of the Solomons the ideas at the core of the tragedy between 1998 and 2003 were trite and unreasonable. Those of us in the media who were trying to make sense of what was hap-

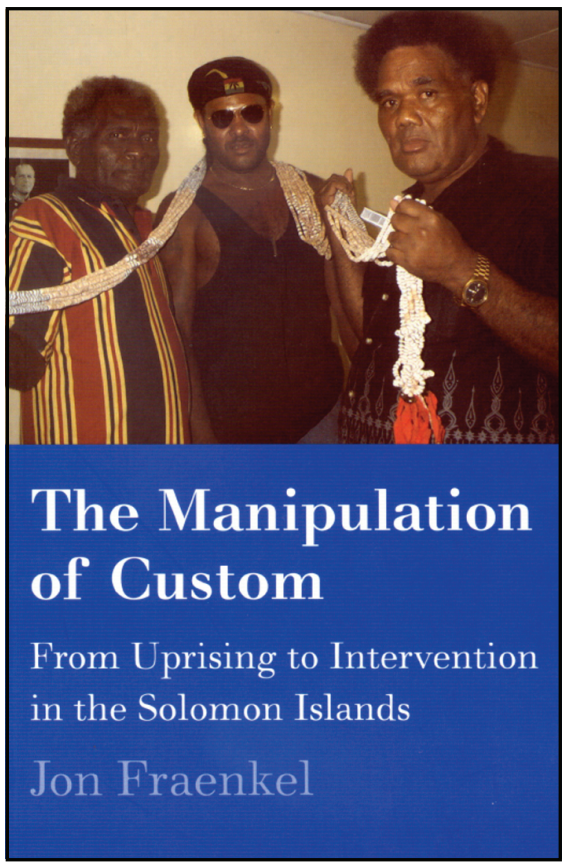

pening could not get enough ink or air time because not enough people were dying and there was no obvious horror story. It was if the marketplace of ideas had already factored in the irrationality of Melanesia that had provided the intractable war in nearby Bougainville.

The nature of the Solomons' society is such that picking a starting point for the tragedy is somewhat arbitrary and by necessity has to over- 
look earlier history. Helpfully however, Guadalcanal Premier Ezekiel Alebua defined a starting point with an inflammatory speech on 30 November 1998, in which he called for S\$2.5 million compensation for 25 alleged murders on the island. It spilled out with a group called the Guadalcanal Revolutionary Army (GRA) targeting Malaita Islanders for harassment and, at times, violence. It climaxed with a coup led by the Malaita Eagle Force (MEF) in June 2000, which coming just after Speight's Fiji coup, was offered as further evidence of Melanesian instability.

It is interesting to note that Alebua's initial speech, which had region-wide implications, largely went unreported at the time (the otherwise laudable Pacific Islands Report website out of Hawai'i did not note it) suggesting this growing fascination in the Pacific media for 'spot news' is disguising underlying trends and causes. It is perhaps a measure of those journalists who routinely covered the region that they did know about it but struggled to win story space for it. The Solomon Islands was not so much forgotten; as far as the world media was concerned, it was locked into 1942 and World War Two.

Only after the attack on the World Trade Center in New York, and the international war on terrorism, did the disorder verging on anarchy attract wider attention, leading to the eventual Australian-led intervention in August 2003. That was as much about political self-interest as it was concern for Solomon Islanders.

Dr Jon Fraenkel, a senior research fellow at the University of the South Pacific's Governance and Development Institute, has produced a solid and readable account of the uprising. He was more than an academic, however, and his own journalism, particularly with the Londonbased Economist was among the scraps of evidence that were used to build up Canberra's intervention justification.

This is no criticism of Fraenkel at all, but underscores the modest media coverage the Solomon's unrest was attracting at the time. An otherwise hysterical Australian newspaper story that the Solomon Islands was going to call on Cuba for help also went into the mix.

One of the problems faced by academia and journalists alike, when confronting a situation such as the civil unrest in the Solomon Islands, is that in finding explanations we are turning the inherently emotional and irrational into an easy to understand formula which, once figured out, can provide solutions and governance. Sometimes though it seems people are bad because they are bad. Harold 
Keke offers himself as Exhibit A in this case.

My own experience of some of the MEF and GRA men was that they were not blessed with anything other than an intense and unpleasant racism which might well have had origins in economic and cultural factors, but it was hate all the same.

Fraenkel's work is essentially pessimistic for its exposure of Melanesian kastom and the much abused process of 'compensation' through the crisis. As he relates in detail that now looks pathetic in retrospect, politicians and rebel leaders ruthlessly exploited kastom. Fraenkel is owed a heavy debt of thanks for exposing the base manipulation and itemising it in a useful form that will serve as a solid resource for any researchers coming along later. He writes:

Crucial to analysing the dynamics of the Solomon Islands conflict was the way compensation demands and reconciliation ceremonies were manipulated for provincial or personal gain. Those responsible were not Kastom leaders, biding their time while the shaky edifice of Westminster government crumbled. They were people who had once enjoyed positions at the helm of that nation state, and in the unsettled atmosphere occasioned by the Isatabu uprising sought new strategies to rejuvenate their fading political careers. They were outsiders who had tasted the fruits of being insiders.

The insurgent movements might have attracted a groundswell of under-employed youth in Guadalcanal and Malaita,

but both were initiated by ex-national politicians who found in them convenient new weapons to deploy in their challenges to the government of the day. In both cases, the younger commanders and foot soldiers who had been summoned up from the streets or villages soon became deeply disenchanted when they saw the fruits of their pyrrhic victories.

Fraenkel does not malign kastom and sympathetically sees it having a function, but his account usefully relates its vulnerability, particularly in a global economy.

The book is particularly useful because of the pathetic state of South Pacific publishing; his footnotes list only a handful of works on the Solomons. He almost apologises to his readers for having been forced to use media sources rather than books. That is not his fault but credit must go to Victoria University Press for this big contribution to the sadly depleted state of Pacific literature. 